Article

\title{
Circular Economy in the Construction Sector: A Case Study of Santiago de Cali (Colombia)
}

\author{
Aníbal Maury-Ramírez ${ }^{1, *}$, Danny Illera-Perozo ${ }^{2}$ and Jaime A. Mesa ${ }^{3}$ (D) \\ 1 Engineering Faculty, Universidad El Bosque, Bogotá 111711, Colombia \\ 2 Department of Mechanical Engineering, Universidad de la Sabana, Chía 140013, Colombia; \\ danny.illera@unisabana.edu.co \\ 3 Department of Industrial Engineering, Pontificia Universidad Javeriana, Bogotá 110231, Colombia; \\ mesajaime@javeriana.edu.co \\ * Correspondence: amaury@unbosque.edu.co; Tel.: +57-164-89000 (ext. 1285)
}

Citation: Maury-Ramírez, A.; Illera-Perozo, D.; Mesa, J.A. Circular Economy in the Construction Sector: A Case Study of Santiago de Cali (Colombia). Sustainability 2022, 14, 1923. https://doi.org/10.3390/ su14031923

Academic Editor: Castorina

Silva Vieira

Received: 11 December 2021

Accepted: 3 February 2022

Published: 8 February 2022

Publisher's Note: MDPI stays neutral with regard to jurisdictional claims in published maps and institutional affiliations.

Copyright: (C) 2022 by the authors. Licensee MDPI, Basel, Switzerland. This article is an open access article distributed under the terms and conditions of the Creative Commons Attribution (CC BY) license (https:// creativecommons.org/licenses/by/ $4.0 /)$.

\begin{abstract}
The circular economy, a new paradigm of technological and economic development, is of great importance in developing countries, particularly in the construction sector, one of the most relevant in Colombia. In the Latin American context, Colombia has one of the most important construction industries, contributing to the social and productive development of the country. However, this sector is also responsible for serious environmental problems and social conflicts. Therefore, it is imperative to work with all actors of the value chain to transform the construction sector from a linear economy to a circular economy model. Therefore, this article describes the circular economy model proposed for Santiago de Cali, which is mainly oriented to the analysis and efficient use of construction materials, mostly taking into account the recovery of ecosystems and the circular flow of rocky materials. This model includes an analysis of the production of construction materials, construction process, use and operation, and completion of the life cycle of buildings and infrastructure. In particular, the model proposes an innovative product portfolio for the use of construction and demolition waste (C\&DW) supported in applied research (case studies). The portfolio consists of family products, such as recycled aggregates or eco-aggregates, eco-concretes and mortars, eco-prefabricated products and modules, and smart construction materials. In addition, this model describes the C\&DW management system and some characteristics of the Technological and Environmental Park (TEP), the main strategy for C\&DW valorization in the city.
\end{abstract}

Keywords: construction and demolition waste (C\&DW); circular economy; construction; concrete; recycling

\section{Introduction}

The rapid growth of the Colombian population and its displacement to urban centers in the last 50 years has indirectly stimulated the development of the national construction sector, which represents one of the most relevant in the economy of Valle del Cauca and Santiago de Cali (approx. 3 million habitants), promoting a large number of jobs (direct and indirect) and energizing other subsectors of the economy of the Colombian southwest. According to the Colombian Chamber of Construction (CAMACOL), the national construction sector currently generates annual investments of 77 billion pesos (USD 19.5 million), contributes 46 billion pesos (11.7 million USD) to the economy, demands inputs for COP 34 billion ( USD 8.6 million) annually and, together with real estate activities, this generates 1.8 million jobs [1]. In addition, this industry has been relevant in improving the infrastructure for land and air connectivity, the development of the housing sector, the provision of public, hospital, educational services, and the growth of business, tourism, and commercial activity in the Colombian southwest region (Pacific coast). However, mainly due to the segmentation and disconnection of all stakeholders within the value chain, lack of control, and the ignorance of the environmental impacts by all the actors, serious problems have been generated in the Valle del Cauca and, particularly, in the city of Santiago de Cali, 
which has a rich environment and cultural background. The environmental deterioration of the seven hydrological basins of the rivers across the city is significant, due to the extraction of raw materials caused by handcrafted and illegal mining. Likewise, the proper disposal of construction and demolition waste (C\&DW) has become a great challenge for the region. Daily, in the city of Santiago de Cali are generated approximately $2500 \mathrm{~m}^{3}$ of rubble or C\&DW, occupying one of the first places among the Colombian capitals in the generation of this type of waste [2].

Due to the above and in order to improve this situation, the circular economy model for the construction sector of Santiago de Cali seeks to transform the construction sector from a linear model (extraction, production, consumption, and waste disposal) to a more circular model. Since 2012, with the support of the Ellen MacArthur Foundation, the circular economy concept (CE) has gained popularity worldwide. Nevertheless, its development really comes from much earlier times. For example, Agenda 21 of 1992 established, in Principle 8, that "states will have to reduce and eliminate unsustainable patterns of production and consumption". Similarly, the Rome Club in 1972, with a report on "the limits of growth" stated the bases to think about a different economy, one that was no linear [3].

Therefore, considering the sustainable development goals (SDGs) stated by United Nations in 2015, particularly SDG 12 on sustainable consumption and production, the proposed model appropriates the circular economy as a production and consumption system that promotes efficiency in the use of materials, water and energy, taking into account the resilience of ecosystems and the circular use of material flows through the implementation of technological innovations, alliances and collaborations between stakeholders (e.g. raw material producers, building companies, users and final disposal actors), and the promotion of business models that respond to the fundamentals of sustainable development [4] Therefore, this pioneer model takes into account the following challenges and opportunities to implement circular economy in construction:

(a) Most of the barriers to implementation are related to organisational concerns [5];

(b) There still exists ambiguity and inconsistency in the assessment methods to measure circularity in building projects [6];

(c) Digitalization could be a great help in developing sustainable circular products [7];

(d) The customers' involvement is necessary for creating innovative sustainable circular products using digitalization [7];

(e) The inclusion of people driven factors in the adoption of circular economy practices in the supply chains [8].

The next sections of this article are organized as follows: Section 2 describes the generalities of the circular economy model proposed for Santiago de Cali. Section 3 corresponds to the Technological and Environmental Park (TEP) proposal that integrates C\&DW from Santiago de Cali to promote different circular services and products for the construction sector. Case studies related to the potential of the TEP are described in Section 4. Finally, challenges and conclusions are included in Sections 5 and 6, respectively.

\section{CE Model Proposal}

Although not presented in this article due to the limited space, the circular model for the construction sector of Santiago de Cali required a previous study from the different actors and their environmental and social impacts through the entire construction value chain. In this study, extractors of raw materials (mining), building materials producers, transporters, construction companies, promoters, maintenance, repair and rehabilitation businesses, certifiers and laboratories, construction and demolition waste managers, other economic sectors of interest to symbiosis, the community and the media were included. Thus, this section describes the phases and product portfolio considered around the CE model adapted to the potential and context of Santiago de Cali. The summary of data and analysis of C\&DW potential were based on previous research projects that support the need for integrative solutions based on material circularity. Phases and product portfolio are 
explained in detail as follows. In addition, the references of the previous research projects are included.

\subsection{Phases of the CE Model for CEDW Materials}

Four phases are considered in the CE model for C\&DW of Santiago de Cali: (i) extraction of raw materials and building material production, (ii) construction, (iii) use and operation, and (iv) end of the lifecycle. It is possible to find recovery flows in such phases to enable a circular economy model (Figure 1). Each phase is described in detail as follows.

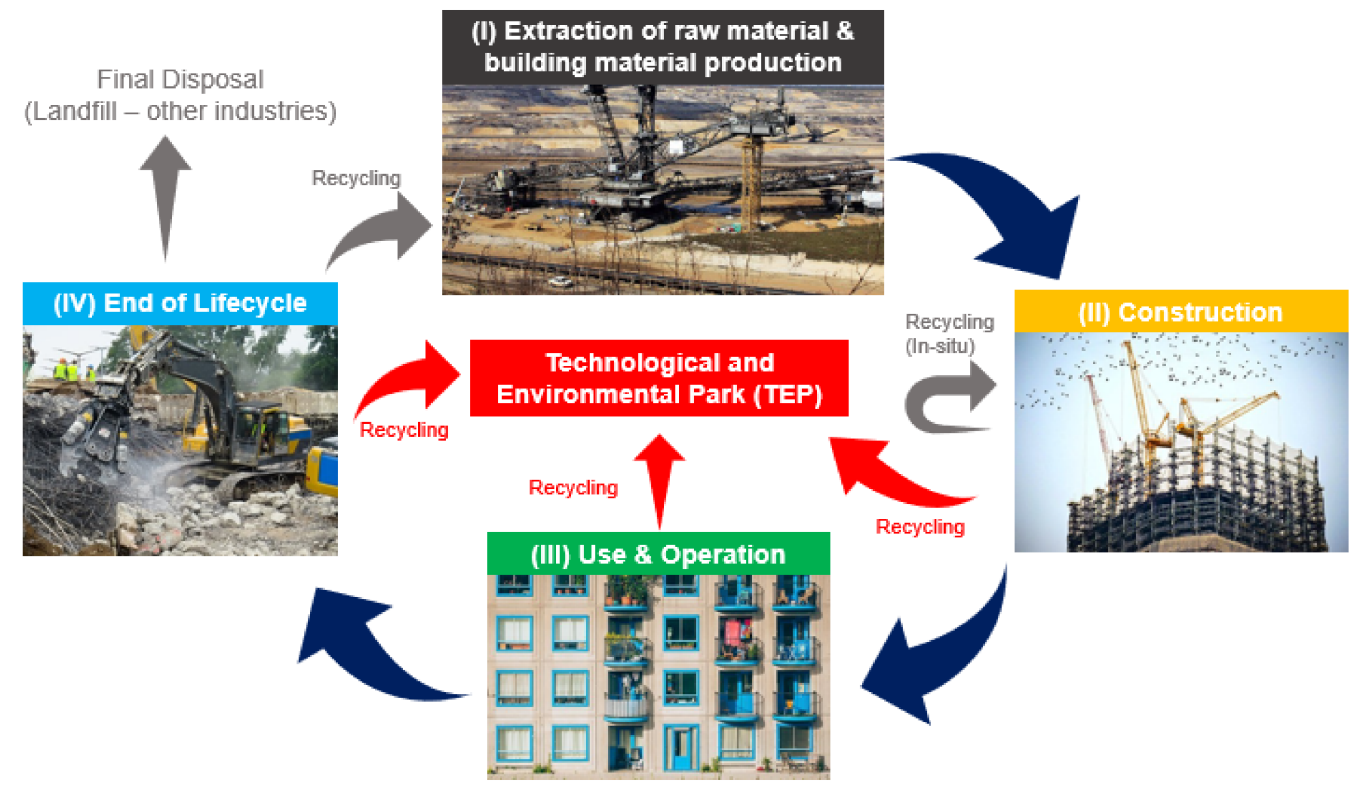

Figure 1. Circular economy model for the construction sector of Santiago de Cali (Colombia) [9].

\subsubsection{Extraction of Raw Materials and Building Materials Production}

The production of construction materials encompasses two main stages: extraction of raw materials and their processing, which involve severe environmental and social impacts. Therefore, the circular economy model proposes incorporating the principle of environmental assets extraction and clean production to replace the classic view of the production of construction materials. Within the framework of a green economy, environmental assets are associated with ecosystem services, resources, or the processes of natural ecosystems (goods and services) that benefit human beings. They include products such as drinking water or clean air and processes such as waste decomposition. Based on the above premise, the appraisal of environmental assets is directly related to economics, sociology, and biology.

Clean production attempts to preserve raw materials, water, and energy; while reducing toxic raw materials use, emissions and waste, which may be depleted into the water, atmosphere, and soil. Clean production arises from continuous improvement, quality control and the reengineering of process engineering. Its application advocates reviewing operations and unitary processes that are part of a productive or service activity, intending to find the various possibilities for improvement or optimization regarding the use of resources. Clean production is thus defined as a preventive business management strategy applied to products, processes, and work organization, whose objective is to minimize emissions and discharges at the source, reducing risks to human and environmental health while simultaneously increasing competitiveness. This results from the following actions:

- The minimization and efficient consumption of raw materials, water, and energy;

- The minimization of the use of toxic raw materials;

- The minimization of the volume and toxicity of all emissions generated by the production process; 
- Recycling the maximum proportion of waste in the processing facility;

- Reduction in the environmental impact of building products during their life cycle;

- The development of end of life strategies for building products defined from early design phases.

To articulate the above mentioned principles, the Portland Cement Association (PCA), one of the oldest and most essential production associations in the United States, has created the Concrete Sustainability Hub, a research center at Massachusetts Institute of Technology (MIT) in collaboration with the Ready Mixed Concrete (RMC) Research and Education Foundation. The Hub was founded with the mission to accelerate emerging advances in concrete science and technology and transfer the best available results to engineering practices. The interdisciplinary team of researchers brings together leaders from academia, industry, and government to facilitate knowledge transfer by aligning world-leading research with end user needs. Meanwhile, Hub researchers are investigating concrete from the nanoscale to address the sustainability and environmental implications of the material's production and use. Their research also aims to refine the composition of concrete, reduce greenhouse gas emissions during its production, and quantify its environmental impact and cost over the lifetime of an infrastructure or construction project [10]. The initiatives mentioned above have significantly impacted the cement industry worldwide. In Colombia, many concrete and cement companies are currently expanding their portfolio of sustainable products based on reducing energy and water consumption during production.

\subsubsection{Construction of Buildings and Infrastructure}

The construction of a building or infrastructure is the macroprocess of the materialization of architectural and engineering projects (e.g., structural, hydraulic, sanitary, electrical and telecommunications networks) arising as a response to a set of global needs that the project must satisfy during use or operation. However, to achieve that objective, it is necessary to work on three main phases: prior and simultaneous coordination and the follow up of the executed project. In particular, these phases seek the formulation and development of construction techniques to ensure optimal water consumption, energy, and materials and the minimum emission of particulate matter, gases, and noise generation. These techniques allow the development of sustainable construction principles, minimize labor risks, reduce costs, and improve the quality of the works.

Here, it is crucial to define a methodology for developing an integrative project considering the large number of professional specialists involved in the construction phase of buildings and infrastructure. In this sense, the stages proposed by [11] are considered according to the Colombian Regulation NSR-10: Construction, Supervision, and Technical Supervision of Structural Concrete Buildings. Coordination phases are described as follows:

- Preliminary/prior coordination: refers to the understanding of the architectural project when it is not yet defined, and only the criteria indicated by the designer are established. The aim is to establish alternatives to the structural system, type of foundation, the possible location of screens, the magnitude of column spacing and dimensions, height of slabs and characteristics of probable materials, among other aspects.

- Simultaneous coordination: As these projects' architectural and structural definitions progress, knowledge is shared among the design professionals. The impact of the definitions is derived from the dimensioning of the structural elements or aspects that the architecture proposes as the project's conceptual basis is established simultaneously.

To facilitate the development of the proposed methodology under the principles of sustainable construction, technological tools that facilitate interdisciplinary and simultaneous work for the execution of architectural and engineering projects are required. For example, building information modeling (BIM) is a collaborative work methodology applied to the construction sector, a collection of organized data of a building to facilitate the management of engineering, architecture, and construction projects achieving improvements in the result and efficiency in the processes $[12,13]$. All professionals involved in a construction project can work on a single project in real time, with access to the same 
information. BIM is associated with geometry, site relationship, geographic information, quantities and the properties of a building or infrastructure components. For example, details of door manufacturers or the energy data of a material can be easily consulted at any stage of the project. In general, BIM can be used to provide information on a building or infrastructure at any time. For example, progress in structural design, maintenance activities and even rehabilitation and demolition processes. Shared material quantities and properties can be easily extracted. In addition, labor aspects, component details and the sequences of construction activities can be isolated and defined. BIM software can achieve such improvements through graphical representations of the parts and components used to construct a building or infrastructure.

Although modularization and prefabrication are technologies that have been used for centuries in the construction industry, their re-emergence as a new trend is associated with the rise of BIM and the requirements of sustainable construction. In particular, modularization refers to the process of manufacturing functional units in controlled offsite environments so that they can be transported in whole pieces from their place of manufacture to their final location. Prefabricated elements include structural elements (e.g., beams, columns, porticos) and nonstructural elements (e.g., pavers, curbs, sidewalks) that make up the functional units (e.g., structural system, foundation). The benefits of using precast and modularization in construction include savings in project schedules, reduction in contingencies, cost optimization for personnel and materials, safety, quality, minimization of $C \& D W$ and potential for reuse of modules and precast at the end of the life cycle of buildings and infrastructure [14]. Recently, robotization and 3D printing have emerged as technologies that seek to articulate the construction industry to the demands of environmental, economic, and social sustainability. In particular, 3D printing is the fabrication of structural and nonstructural elements by layering layers of material, just as in paper printing. Even with significant challenges, 3D printing has already been applied to constructing houses, footbridges, and canals in Europe and Asia [15].

\subsubsection{Use and Operation of Buildings and Infrastructure}

Although it would seem that buildings and infrastructure projects during their operation and use do not have much environmental impact, the truth is that water and energy consumption, as well as the generation and management of solid waste, constitute a severe problem for the sustainability of the planet [16]. This problem has become even more acute due to the increase in the use and operation of residential buildings to prevent the spread of COVID-19, environmental contingencies associated with poor urban air quality, and even social protests that have turned homes into places of work and leisure [17]. Therefore, responsible use and consumption has become a new lifestyle paradigm for society. Responsible consumption is a concept that considers that humanity would change its consumption habits by adjusting them to its real needs and opting in to the market for goods and services that favor environmental conservation, social equality, and the welfare of the less favored classes. Responsible consumption is a way of consuming goods and services considering, in addition to the variables of price and quality, the social and labor characteristics of the production environment and the subsequent environmental consequences. Therefore, this model incorporates technological tools for the management and use of C\&DW, efficient use of energy and water in buildings and infrastructure and constitutes a training tool for users of buildings and infrastructure in the search for sustainable lifestyles.

\subsubsection{End of Lifecycle}

Buildings and infrastructure are exposed to the mechanical action of service loads and other factors, such as environmental factors, which tend to deteriorate and destroy them (i.e., physical, chemical, and biological actions), leading to the termination of their life cycle [18]. Depending on the level of damage and economic resources, maintenance, repair, rehabilitation and repowering activities are prioritized over demolishing a building or infrastructure. These activities are prioritized because, with their relatively low cost 
and environmental impact, they can significantly increase the useful life of a building or infrastructure. This approach is particularly useful in urban centers, where it is also possible to preserve the architectural and historical heritage of the cities. The above premise raises the need to incorporate architectural flexibility or transformable architecture in the design of buildings and infrastructure. The history of civilizations has shown the importance of rethinking the use of buildings and infrastructure. This principle has been fundamental to solving problems ranging from food and shelter from the elements to battlefield logistics. Flexibility has been used in experimental and lightweight structures for institutions, commerce, and housing. In particular, flexible architectural design aims primarily at adapting and changing to the user's needs and the environment. This position is contrary to traditional architectural design, which, to a greater extent, is fixed or static towards the needs of man. Thus, flexible architecture redesigns itself over time because it allows it to develop, eliminate, and modify parts, keeping the structure in continuous service. The benefits of flexible architectural design include low cost, lower environmental impact, greater creative field, but, above all, it allows the development of a transitional architecture and search for ingenious solutions in times of need and scarcity, such as the one in which humanity is currently living [19].

However, in cases where, after an integrated analysis, it is found that the total or partial demolition of a building or infrastructure is necessary, the process must be carried out considering the environment and societal impacts. Therefore, it is imperative to consider demolition as the opposite process to construction, which includes well designed sequential operations. This conceptualization of the demolition process is also known today as deconstruction (Figure 2). Within the framework of the deconstruction process, selective demolition has become an advantageous technique for the utilization of CDW. The main objective of this demolition technique is to improve the classification and use at the source, extending the life cycle of construction materials, favoring reuse and generating less waste whose final destination will be the landfill. The technique consists of dismantling architectural finishes (e.g., floors, windows, doors), the heating-ventilation systems and, finally, the demolition of the structure, starting with the superstructure and then the foundations. It is important to mention that the foundation waste is challenging to use because of its continuous exposure to groundwater and soil minerals.

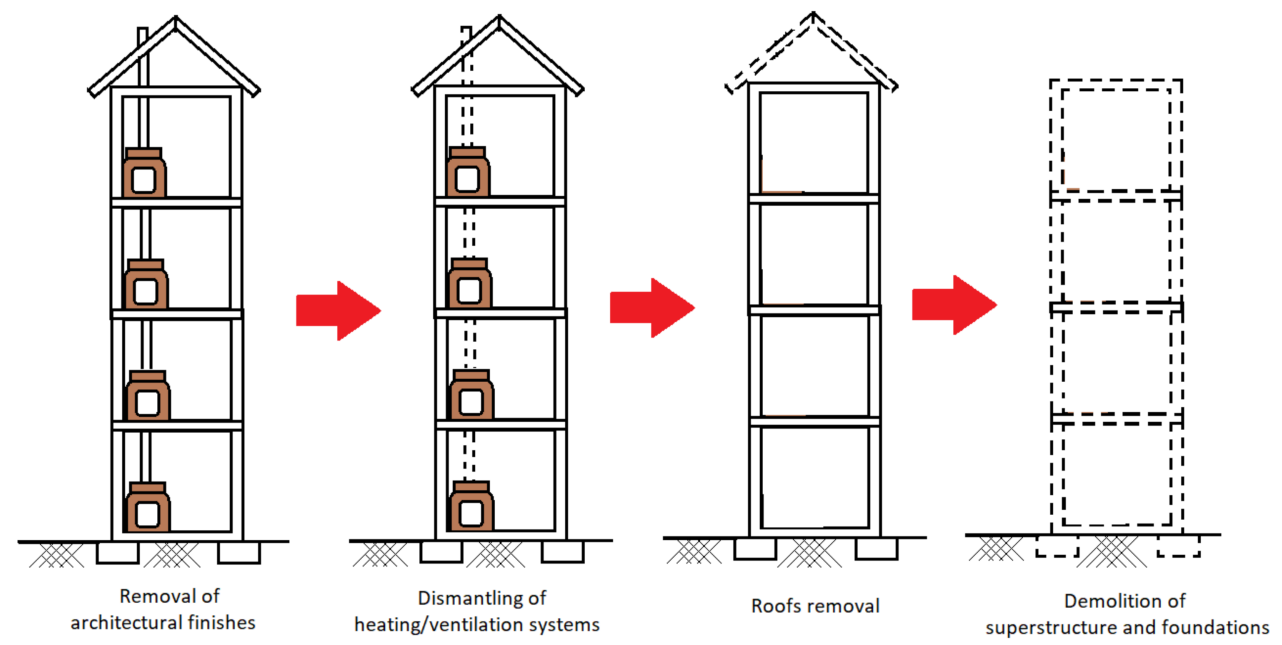

Figure 2. Sequence for the deconstruction process of a building. Adapted from [20].

\section{Technological and Environmental Park (TEP) Project}

Santiago de Cali's Technological and Environmental Park will be a public-private initiative that integrates highly trained human resources and a modular and flexible platform for researching and developing an innovative C\&DW based construction materials portfolio. Therefore, in addition to the technology required for creating the product portfolio, 
a materials laboratory will be included for the adequate physical, chemical, mechanical, durability, and environmental impact characterization of the products developed. This laboratory will be linked to the region's network of universities with extensive experience in this area.

It is worth noting that the use of $C \& D W$ is developed under the principle of the 7Rs (rethink, redesign, reuse, repair, remanufacture, recycle and recover), an initiative on consumption habits, initially promoted by Greenpeace as 3Rs (reduce, reuse and recycle), which seeks to encourage habits such as responsible consumption. This concept refers to waste management strategies that seek to be more environmentally responsible, prioritizing reducing the volume of waste generated over reuse and recycling. These processes generally consume more energy and involve higher environmental and economic impacts. However, given that, in Santiago de Cali, approximately $2600 \mathrm{~m}^{3} /$ day of C\&DW is generated with a percentage of $96 \%$ usable due to its ceramic nature [21], this model offers specific tools for onsite recycling (in situ) and in the TEP. Table 1 summarizes the consumption of construction materials for Santiago de Cali.

Table 1. Consumption of construction materials according to the constructive system in Santiago de Cali [21].

\begin{tabular}{|c|c|c|c|}
\hline Materials & $\begin{array}{c}\text { Industrialized } \\
\text { Prefabricated } \\
\text { Products }\left(\mathrm{kg} / \mathrm{m}^{2}-\%\right)\end{array}$ & $\begin{array}{l}\text { Structural Masonry } \\
\left(\mathrm{kg} / \mathrm{m}^{2}-\%\right)\end{array}$ & $\begin{array}{l}\text { Masonry Confined } \\
\text { with Porches } \\
\left(\mathrm{kg} / \mathrm{m}^{2} \mathrm{-} \%\right)\end{array}$ \\
\hline Aggregates & $542.19-42.7$ & $404.05-29.3$ & $624.99-26.0$ \\
\hline River sand & $445.21-35.1$ & $349.09-25.3$ & $733.63-30.5$ \\
\hline Grey cement & $156.74-12.4$ & 138.78-10.1 & $306.12-12.7$ \\
\hline Rock (excavation soil) & $46.6-3.7$ & $152.24-11.0$ & $372.52-15.4$ \\
\hline Fired ceramics & $39.98-3.2$ & $301.28-21.9$ & $358.08-14.9$ \\
\hline Steel & $26.68-2.1$ & 20.31-1.5 & $9.44-0.4$ \\
\hline Wood & $5.02-0.4$ & $3.58-0.26$ & $0.13-0.0$ \\
\hline Roof tiles & $3.15-0.25$ & $5.92-0.43$ & - \\
\hline PVC & $2.35-0.19$ & $2.06-0.15$ & $2.39-0.1$ \\
\hline Copper & $0.42-0.03$ & $0.13-0.01$ & - \\
\hline White cement & $0.37-0.03$ & $0.48-0.03$ & - \\
\hline Paint & $0.32-0.03$ & $0.55-0.04$ & - \\
\hline
\end{tabular}

Recycling is conceived as an environmentally friendly process that seeks to convert construction and demolition waste into new products for subsequent use in the construction sector and other sectors of the regional economy. Recycling avoids the disuse of potentially valuable materials that would typically be disposed inappropriately or at a high cost. This technology reduces the consumption of new raw materials to manufacture construction materials which, according to ACODAL (2017), are dominated in Santiago de Cali by masonry confined with frames $(46.4 \%)$, prefabricated $(27.2 \%)$, structural masonry $(22.4 \%)$ and other systems $(4 \%)$. Therefore, to satisfy the demand for the above construction materials, guaranteeing their mechanical properties and durability together with a significant reduction in environmental impact, the circular economy model, through the TEP, presents the following family of products (Table 2):

\section{(a) Recycled aggregates or eco-aggregates}

In addition to the massive and traditional use of aggregates in concrete and mortar, aggregates have recently been used to generate permeable surfaces, vegetated surfaces (green roofs and green walls) and sustainable urban drainage systems (SUDS). Eco-aggregates or recycled aggregates are granular materials with physical, chemical, and mechanical properties that meet the conditions of mechanical strength and durability for the different applications described.

(b) Eco-concretes and mortars 
Concrete and mortar are the most widely used building materials in the regional, national and global construction sectors. Eco-concretes seek to replace the most critical components of traditional concrete, such as aggregates (fine and coarse) and portland cement, with recycled aggregates and supplementary cementitious materials such as ashes and slag. The latter being byproducts of other productive sectors such as thermoelectric plants and agribusiness. Eco-concretes and mortars may be used in buildings and infrastructure when they meet Colombian regulations' mechanical strength and durability conditions.

\section{(c) Eco-prefabricated products and modules}

These elements belong to construction systems based on the design and production of components and subsystems that are mass produced in a factory away from their final location and brought to their final position to assemble the building or infrastructure after a relatively simple and precise assembly phase. The eco-prefabrications proposed in this manual include structural elements (e.g., beams, columns, slabs, frames) and nonstructural elements (e.g., blocks, pavers, curbs, and sidewalks).

\section{(d) Smart construction materials}

These are active and adaptive materials that can respond in an autonomous, functional, and controlled manner to changes in their condition or the environment to which they are exposed to. Self-cleaning concrete and mortars with the capacity to purify the surrounding air stand out. These materials, incorporating titanium dioxide $\left(\mathrm{TiO}_{2}\right)$ nanoparticles, when exposed to solar energy (UV-A fraction), can generate a photocatalytic process to degrade organic and inorganic pollutants, both in solid and gas phases. Such materials have been used in buildings and infrastructure worldwide.

Table 2. Materials and infrastructure considered in the product portfolio.

\begin{tabular}{|c|c|c|}
\hline Material/Product & Description & Example \\
\hline Recycled Aggregates & $\begin{array}{l}\text { Employed during construction projects to generate permeable } \\
\text { surfaces, green roofs (walls and roofs), and urban drainage } \\
\text { systems. Aggregates are granulated materials with physical, } \\
\text { chemical, and mechanical properties that fulfill specific } \\
\text { mechanical strength and durability requirements. }\end{array}$ & \\
\hline Eco-concrete and mortars & $\begin{array}{l}\text { The most widely used construction materials in the regional, } \\
\text { national, and global construction sectors. Eco-concretes seek to } \\
\text { replace the most critical components of traditional concrete, such } \\
\text { as aggregates (fine and coarse) and portland cement, with } \\
\text { recycled aggregates and supplementary cementing agents such as } \\
\text { ash and slag, the latter byproducts from other productive sectors } \\
\text { such as thermoelectric plants and agribusiness. }\end{array}$ & \\
\hline $\begin{array}{l}\text { Eco-prefabricated } \\
\text { products and modules }\end{array}$ & $\begin{array}{l}\text { These elements belong to construction systems based on the } \\
\text { design and production of components and subsystems produced } \\
\text { in series in a factory outside their final location. They are brought } \\
\text { into their final position to assemble the building or infrastructure } \\
\text { after a relatively simple assembly phase and precise. } \\
\text { Prefabricated products include structural (e.g., beams, slab } \\
\text { columns, frames) and nonstructural (e.g., blocks, paving stones, } \\
\text { gutters, curbs, and platforms) elements. }\end{array}$ & \\
\hline
\end{tabular}


Table 2. Cont.

\begin{tabular}{cc}
\hline Material/Product & Description \\
\hline $\begin{array}{c}\text { Active and adaptive materials that can respond autonomously are } \\
\text { helpful and controlled to changes in their condition or the } \\
\text { environment they are exposed to. Self-cleaning concretes and } \\
\text { mortars stand out, with the ability to purify the surrounding air. } \\
\text { Thaterials }\end{array}$ & $\begin{array}{c}\text { The materials, incorporating nanoparticles of titanium dioxide } \\
\text { generate a photocatalytic process of degradation of organic and } \\
\text { inorganic pollutants, both in the solid and gas phases. }\end{array}$ \\
\hline
\end{tabular}

\section{Management and Use of C\&DW}

It is worth noting that the recycling of C\&DW is not a substantially new technique in the construction sector; the first modern scientific reports date back to the 1940s in Central Europe, with a substantial increase in the 1970s due to the research developed by the Building Contractors Association (BCA) and the Ministry of Public Works (Japan) after the oil crisis. Today, this Asian country has a system for the exclusive use of C\&DW, mainly for flexible pavements in sub-bases. In Taipei, interest is growing in the use of concrete waste. It is estimated that close to $90 \%$ is recovered, with $95 \%$ of old concrete being used. In the Netherlands and Finland, robust legislation has been put in place that allows almost all C\&DW to be recovered, except at the production stage. More recently, 38 US states have approved recycled aggregates in road subbases, and 11 states allow it in new concrete. Brazil already has C\&DW recycling plants, particularly Belo Horizonte and Sao Paulo. Although there are significant differences between the rates of C\&DW utilization in northern, central, and southern Europe, due to its legislative and technological progress in the utilization (reuse and recycling) of C\&DW, this region is of great interest to the world. Precisely, the European Community, which had a 28\% utilization rate, intended to reach an average utilization rate of $70 \%$ for the 15 member states by 2020 [23].

In Colombia, although there is an adjustment in progress, it is expected to reach at least 2032 using 30\% of usable C\&DW in the total weight of the materials used for construction [24]. Considering the above, the European Standard EN 12620 (2002) is proposed to classify construction and demolition waste for the Technological and Environmental Park. With a higher level of detail than the one proposed in Resolution 472 of the Ministry of Environment and Sustainable Development (2017), this standard allows better use of C\&DW. This standard is based on eight main waste groups and seven categories indicating the composition of the leading group.

\subsection{Technical Assessment for New Materials and Products}

The product portfolio is designed and fabricated based on the type of C\&DW material, considering ashes and slag and the technical requirements such as mechanical strength and durability. Therefore, due to the mixture design of these new materials it is necessary to perform a rigorous research process that includes the first phase of physical, chemical, and mechanical characterization of each of the mixture components, highlighting the characterization of the aggregates from C\&DW, ashes, slags, and new components such as nanomaterials. Using recognized mix design methods, the design and fabrication of the test mix proceed based on this information. Subsequently, the evaluation of properties before hardening for mixtures is carried out, measuring consistency and fluidity. When these mixtures satisfy the conditions for placing the product for concretes and mortars fabricated in situ (or prefabricated products), mechanical and durability evaluation in the hardened state is developed according to the demands of the building or infrastructure. Similarly, autonomic properties such as self cleaning and air purification are evaluated in 
the case of smart building materials. Figure 3a summarizes the process for the technical assessment of mixtures from C\&DW.

Characterization of C\&DW materials (Chemical, physical, mechanical, durability)

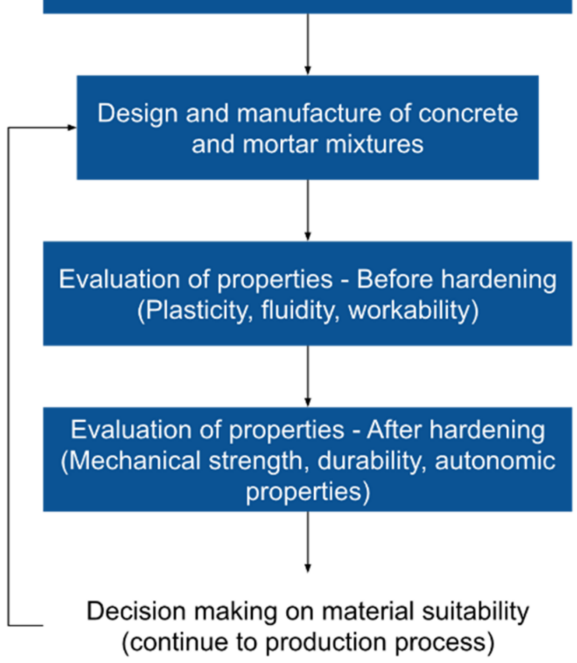

(a)

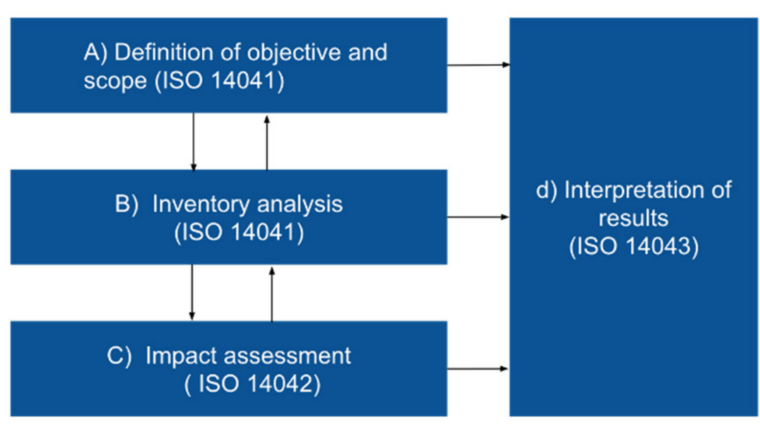

(b)

Figure 3. (a) Diagram for the technical assessment for developing new materials and products in the TEP of Santiago de Cali. (b) LCA process to study the TEP product portfolio Adapted from [23].

Although the mixture design methods serve as a guide for an adequate proportioning of the components, the design process with recycled aggregates, other residues and nanomaterials demands a recurrent adjustment depending on the characteristics in the state before and after hardening until the final mix design and the manufacturing process are obtained. The reliability of the results is based on the experimental design that uses the comparison with concrete and mortar mixtures, which, using natural aggregates and conventional cement, meet the same mechanical and durability requirements.

In addition to the technical assessment, a life cycle analysis (LCA) will be developed to measure and improve the sustainability performance of new products and materials. This tool assesses a product or service's environmental and social impacts during all stages of its existence: extraction, production, distribution, use, and end of the life cycle. LCA involves quantifying resource consumption (energy, water, and materials) and environmental emissions to air, water, and soil associated with the system being evaluated. According to the ISO 14040-14043 standards, the LCA consists of four stages: (a) definition of the objective and scope, (b) creation of the inventory, (c) evaluation of the impact and (d) interpretation of results (Figure $3 b$ ).

The first stage of the definition of the objective and the scope must define the application and intended use of the results and users (target audience). The typical objectives of an LCA study are to compare two or more products that fulfill the same function (e.g., concrete with natural aggregates and concrete with recycled aggregates), to identify possibilities for the improvement of existing products, or even the innovation and design of new products. The definition of the scope of an LCA study involves the establishment of the limits of the evaluation. The following elements should be clearly described in the scope definition: the system to be studied and its function, the functional unit, the system boundaries, types of impact and impact assessment methodology, data quality requirements, assumptions and limitations [25].

Inventory analysis is the second stage in an LCA. This involves data collection and calculation procedures to quantify a product system's relevant inputs and outputs. These inputs and outputs include using resources, emissions to air, water, and soil, and generating 
waste associated with the system. The inventory analysis must be supported by a process tree (process diagram, flow tree) that defines the phases in the life cycle of a product. Each of the different phases can be composed of the different unit processes, for example, production with different types of raw materials to combine in the production phase of the material. Transport processes often connect the different phases. Data on material, water, energy consumption, waste, and emissions must be collected for all process units in a product's life cycle [23].

In the third stage, the potential environmental impacts of the modeled system are evaluated. This stage consists of three mandatory elements: (i) selection of impact categories, category indicators, and characterization models, (ii) classification and (iii) characterization. The impact categories are selected to describe the impacts caused by the analyzed product or product family. This is a follow up to the decisions made in the targeting and scoping phase. Some of the impact categories that are usually considered are the consumption of nonrenewable sources, water consumption, global warming potential, ozone layer depletion potential, eutrophication potential, acidification potential, the potential for the formation of smog, human toxicity (carcinogenic and noncarcinogenic), ecological toxicity, waste generation, land use, air pollution and alteration of habitats.

Finally, the interpretation of results is the fourth phase of the LCA. It includes the following main aspects: identification of significant environmental problems, evaluation of results to establish their reliability (integrity, sensitivity, and coherence), conclusions and recommendations.

\subsection{Technology for Obtaining Recycled Aggregates from CEDW}

The process that seeks to separate materials from paper, polymers, wood, steel, soil and other contaminants must follow several steps to guarantee the obtention of adequate recycled aggregates. Figure 4 shows the overall process to separate different materials from C\&DW. This process should include previous weighing and drying, important information and condition, respectively, to manage the following steps. Particularly, weighing can be carried out by a weighing scale for trucks or a load cell in hoppers. In general, the selection of technologies for the process are recommended using criteria such as initial investment, energy consumption, dust emissions, maintenance cost and useful life.

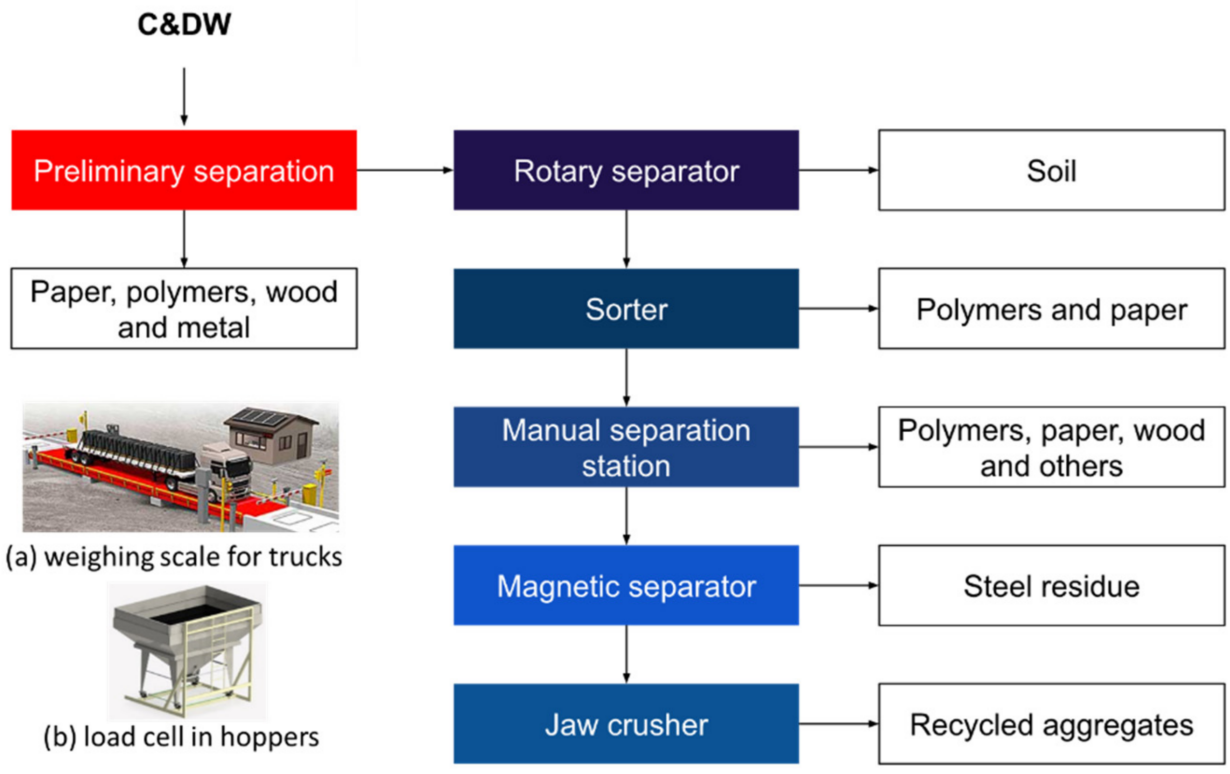

Figure 4. Separation process for the production of recycled aggregates from C\&DW. Adapted from [20]. 


\section{Case Studies}

The product families and methodologies proposed in the circular economic model for construction are mainly supported by previous research in the Master Program of Civil Engineering at the Pontificia Universidad Javeriana de Cali. Below are some case studies of great value for the proposed circular economic model (Figure 5).

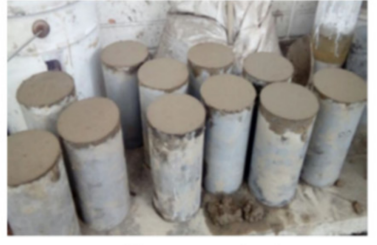

Eco-concrete

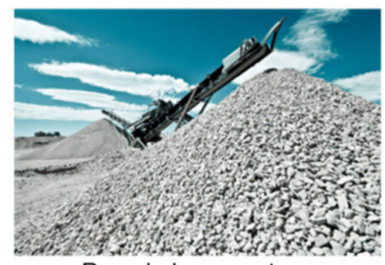

Recycled aggregates

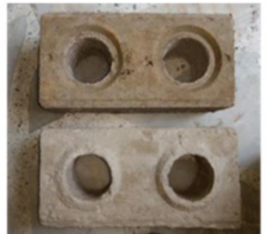

Eco-bricks

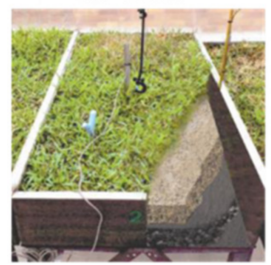

Green roofs

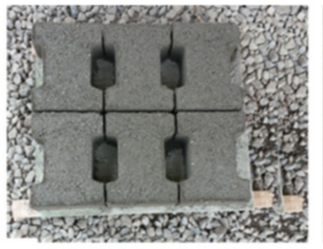

Paving stones

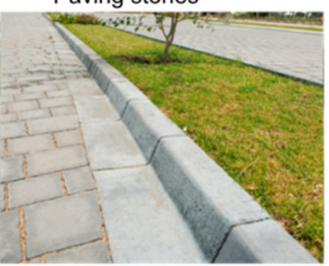

Curbs and ditches

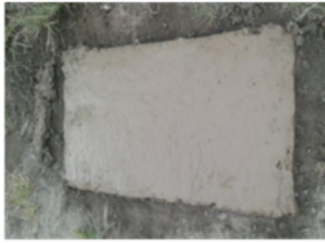

Eco-sidewalks

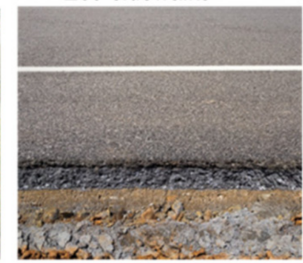

Eco-pavements

Figure 5. Family of ecoproducts from the TEP of Santiago de Cali.

\subsection{Paving Stones}

In this research project, the resistance to the bending and compression of nine concrete mixtures (called M1 to M9) with partial and total replacements of the fine and coarse natural aggregate by recycled aggregate from the crushing of concrete paving stones from the Plaza of the Municipality of Almaguer (Cauca, Colombia) were evaluated. The methodology followed included five phases, from sampling the aggregates to selecting the concrete mixes with the best mechanical performance for their use in new paving stones. The results showed that the concrete mixtures replacing $50 \%$, by weight, of the fine natural fraction (called M2) and 50\%, by weight, of the natural coarse fraction (called M4) meet the strength required by the NTC-2017 to manufacture new paving stones. Although techniques should be investigated to improve the wear resistance of concrete mixtures when used as paving stones, the percentages of use of recycled aggregates presented in this project concerning those reported in the literature are much higher. Therefore, the solution proposed in this project not only has the potential to significantly reduce the negative environmental impact caused by the improper disposal of construction waste and extraction of nonrenewable resources, but it also has the potential to reduce costs in construction projects [9].

\subsection{High Strength Concrete}

This research aimed to evaluate the effect of the partial replacement of natural coarse aggregate by recycled concrete aggregate (RCA) on the mechanical properties of high strength concrete (HSC). An experimental methodology composed of five stages was followed: the selection of the concrete residues and subsequent production of the RCA, the characterization of the materials used, the manufacture of concretes with different contents of RCA $(0,10,20$, and $40 \%)$, the determination of the properties in the fresh and hardened state of the above mentioned concretes and, finally, the analysis of the results. It was concluded that the developed HSC not only satisfies the specifications of the Colombian regulations, the incorporation of recycled aggregate also had a positive effect on the mechanical and durability properties of the concretes, obtaining the best performance with the mix using $40 \%$ RCA. Therefore, using HSC with RCA as a construction material is technically feasible, positively impacting the environment by reducing the exploitation of nonrenewable natural resources and extending useful life spans of buildings and infrastructure [26]. 


\subsection{Prefabricated Products}

This project included the diagnosis of construction waste generated in civil projects in the urban area of the city of Pereira (Colombia). Once classified onsite, C\&DW materials were incorporated into prefabricated concrete elements in the same place where they are generated, contributing to the reduction in the exploitation of the natural resource, lower emissions of greenhouse gases, and decrease in land occupation for the disposal of unused waste.

During the project's development, the construction waste from three pilot projects was classified and quantified. From this, components from concrete and natural aggregate were recycled, for which the most relevant physical and mechanical properties were determined through laboratory tests. New concrete mixtures were made with these recycled aggregates, whose mechanical behavior was established through compression and flexural strength tests. The production costs of the recycled aggregate obtained within the source where they were generated were reviewed and compared with market prices, involving activities from the initial phase of the classification process. Some prefabricated elements were manufactured with several samples of these mixtures, and their mechanical behavior was analyzed. The degree of technical and economic viability was finally established for using these recycled aggregates within the same construction activities from which they were obtained and circumscribed to the local conditions of the region related to the city of Pereira [27].

\subsection{Mortar}

Fly ash from the manufacturing process of the paper industry was used for this research because this possesses physical and chemical properties that make them suitable for reuse as substitutes for raw materials for modified mortars, proving the case of the substitution of Portland cement, evaluating the effect that this substitution has on the physical and mechanical properties of the mortar. The research covered the characterization of the raw materials that make up the mortar, the determination of the mechanical properties of the mortar, such as compressive resistance, and the evaluation of the modified mortar as a joining material for structural walls. This study showed that replacing cement in percentages greater than $10 \%$ of fly ash yields a mixture with greater workability but less resistance to traditional mortar. It is concluded that using ash from the paper industry to prepare mortars is mechanically feasible since this material is used in conventional block masonry [28].

\subsection{Green Roofs}

In this research, the hydraulic, thermal and mechanical performance, impact on dead loads, and costs associated to four semi-intensive green roof systems in which recycled (rubber and HDPE plates) and reused materials (PET bottles) were used for the drainage system were evaluated. Then, results were compared with the conventional drainage system that uses the aggregate of natural origin (basalt gravel). For the evaluated environmental conditions, the results showed that some systems (e.g., recycled rubber) can be more useful when the green roof application intends to reduce the temperature, and others (e.g. HDPE plates) when it is the water retention capacity. In addition, the developed green roof systems, using recycled and reused materials, showed the potential to reduce dead loads and costs compared to traditional green roofs [29].

\subsection{Air-Purifing Systems}

It is known that air pollution has a direct negative effect on the quality of life of people and ecosystems (including infrastructure). Considering that one of the main sources of pollutant at the urban level are vehicles, different transit strategies to reduce the use of vehicles have been implemented without much success in Colombia. For this reason, in this project, a system was designed to generate air purification and self-cleaning in the Colombia Avenue Tunnel in Santiago de Cali (Figure 6). To achieve the last objective, 
a mortar and a photocatalytic coating were evaluated, technically and financially, using $\mathrm{TiO}_{2}$ and artificial light with UV-A rays. In this case, to monitor photoactivity, two artificial colorants (methylene blue and rhodamine b) were applied to the surface of the photocatalytic materials, which were exposed in a controlled manner to UV-A rays using a photoreactor. The removal of the mentioned dyes was followed by digital image analysis with ImageJ software. The efficiencies obtained in removing these colorants, which are indicators of the degradation of organic and inorganic pollutants, were simulated in the Street Canyon model (developed by the National Institute for Environmental Research of Denmark), finding promising results for the removal of nitrous oxides, sulfur dioxide, carbon monoxide, and total hydrocarbons [30].
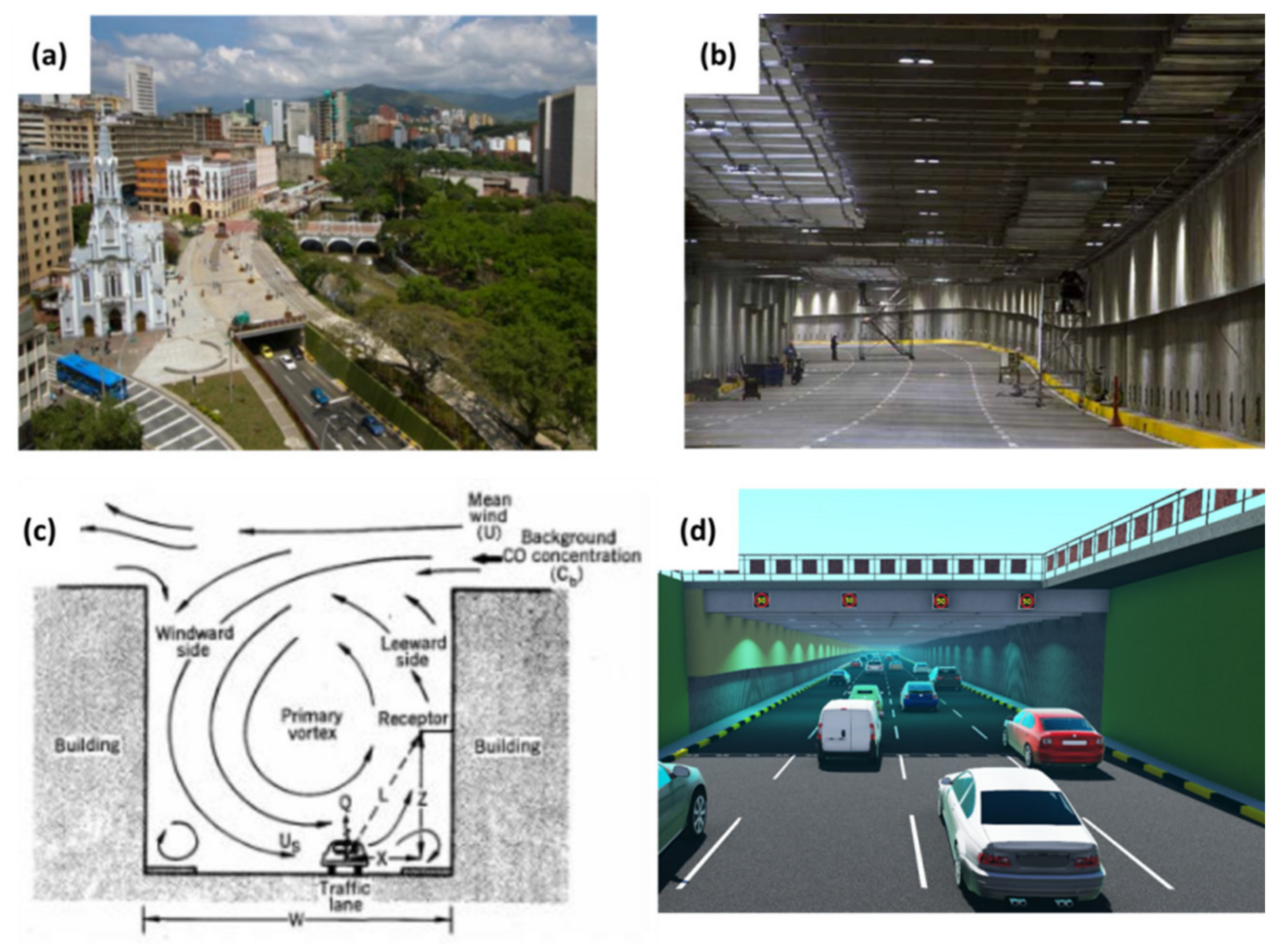

Figure 6. Design of air purification and self-cleaning system in the Colombia Avenue Tunnel in Santiago de Cali. (a) Location of the tunnel, (b) geometric characteristics of the tunnel, (c) model of the air quality used, (d) model of the lighting system and photocatalytic coating. Based on [30].

\section{Challenges to Face}

The proposed circular economy model demands a high degree of innovation for the correct formulation and implementation of concepts and technologies such as the valuation of extraction of environmental assets, the clean production, building information modeling (BIM), robotization, 3D printing, responsible consumption, architectural flexibility, transformable architecture, deconstruction, recycling, and industrial symbiosis. Therefore, the articulated and continuous work between civil society, the government, the business sector, and the academy is proposed to guarantee the proper development of an ecosystem of research, creation, development, innovation, and entrepreneurship.

As a new paradigm of economic development crucial for the postpandemic era, the circular economy generates excellent opportunities for the articulation of the construction sector with vulnerable communities and the environment. In this sense, the proposed model must consider the analysis of energy and water flows in subsequent development and implementation stages, as well as gaseous emissions and particulate matter [31]. Likewise, through tools such as the social life cycle assessment (S-LCA), the assessment of social and sociological aspects are recommended from the production of construction materials, 
construction processes, use and operation, and completion of the life cycle of buildings and infrastructure [32,33].

In addition, in Colombia, legislation is still under development in C\&DW valuation. Therefore, more initiatives are required to accelerate the transition towards a more sustainable ecosystem in the construction sector. Tax benefits and economic support can be implemented to increase the number of companies involved in the construction sector (including logistics, material processing, construction, among others).

\section{Conclusions}

This article presents a technical proposal to manage and increase the value of C\&DW in Santiago de Cali (Colombia) through the development of a Technological and Environmental Park to offer a valuable product portfolio for new construction projects and include benefits in terms of environmental impact more sustainable lifecycle, and cost reduction. Coming from academia, case studies demonstrated that the Colombian southwest region has potential to research and develop new building material products made up of C\&DW. This potential can be increased by creating a sustainable production ecosystem of all companies related to the construction sector, together with disposal actors. Similarly, developing a conscious sustainable users' community will drive the product portfolio. In this way, this model becomes a tool for the business sector, academia and the community, sponsored by the government, particularly for this actor the model becomes a tool of performance measurement and benchmarking, consumers want to make the right environmental choices when buying products. Policy makers want to promote sustainable consumption and production to respond to national and international environmental challenges. In addition, businesses want to improve efficiency to boost margins and competitiveness, while contributing to a sustainable society $[34,35]$. In later stages, the circular economy model proposed for the construction sector of Santiago de Cali must strengthen industrial symbiosis through the valorization of waste of a different nature than ceramic (i.e. C\&DW). For example, the environmental use of polymeric and metallic waste from construction is strategic to reduce the impact of the families of products that make up the TEP portfolio. However, in this first stage, the current construction systems demand will potentially guarantee the model's success with the proposed product families based only on C\&DW.

Author Contributions: Conceptualization and methodology, A.M.-R.; validation, D.I.-P., and J.A.M.; formal analysis, A.M.-R., D.I.-P. and J.A.M.; investigation and resources, A.M.-R.; data curation, D.I.-P. and J.A.M.; writing-original draft preparation, D.I.-P. and J.A.M.; writing-review and editing, D.I.-P.; visualization, D.I.-P.; supervision, A.M.-R. and J.A.M. All authors have read and agreed to the published version of the manuscript.

Funding: This research was partially funded by Alcaldía de Santiago de Cali.

Institutional Review Board Statement: Not applicable.

Informed Consent Statement: Not applicable.

Data Availability Statement: Not applicable.

Acknowledgments: The authors would like to thank the Engineering Faculties of Universidad El Bosque, Universidad de La Sabana, and Pontificia Universidad Javeriana for their support during the development of this project. Additionally, the authors would like to thank the financial support of Alcaldía de Santiago de Cali.

Conflicts of Interest: The authors declare no conflict of interest. 


\begin{abstract}
Abbreviations
ACODAL: Colombian Association of Sanitary and Environmental Engineering, BCA: Building Contractors Association, BIM: building information modeling, CE: circular economy, CAMACOL: Colombian Chamber of Construction, C\&DW: construction and demolition waste, HDPE: high density polyethylene, HSC: high strength concrete, LCA: life cycle analysis, MIT: Massachusetts Institute of Technology, NSR-10: Colombian Regulation of Earthquake Resistant Construction, PET: polyethylene terephthalate, PCA: Portland Cement Association, RMC: ready mixed concrete, RCA: recycled concrete aggregate, S-LCA: social life cycle assessment, SDGs: sustainable development goals, SUDS: sustainable urban drainage systems, TEP: Technological and Environmental Park.
\end{abstract}

\title{
References
}

1. Informe de Gestión 2018-2019-Camacol.co. Available online: https://camacol.co/sites/default/files/descargables/Informe\% 20de\%20Gesti\%C3\%B3n\%202018-2019.pdf (accessed on 10 December 2021).

2. Plan de Ordenamiento Territorial—POT año 2014. Available online: https://www.cali.gov.co/planeacion/publicaciones/106497 /pot_2014_idesc/ (accessed on 10 December 2021).

3. La economía Circular y su Papel en el Cambio Climático. Available online: https://www.elespectador.com/actualidad/laeconomia-circular-y-su-papel-en-el-cambio-climatico/ (accessed on 10 December 2021).

4. Economía Circular-ANDI. Available online: http://www.andi.com.co/Uploads/economia-circular-1-reporte.pdf (accessed on 10 December 2021).

5. Charef, R.; Morel, J.-C.; Rakhshan, K. Barriers to Implementing the Circular Economy in the Construction Industry: A Critical Review. Sustainability 2021, 13, 2989. [CrossRef]

6. Zhang, N.; Han, Q.; de Vries, B. Building Circularity Assessment in the Architecture, Engineering, and Construction Industry: A New Framework. Sustainability 2021, 13, 2466. [CrossRef]

7. Agrawal, R.; Wankhede, V.A.; Kumar, A.; Upadhyay, A.; Garza-Reyes, J.A. Nexus of circular economy and sustainable business performance in the era of digitalization. Int. J. Product. Perform. Manag. 2021. ahead-of-publication. [CrossRef]

8. Sawe, F.B.; Kumar, A.; Garza-Reyes, J.A.; Agrawal, R. Assessing people-driven factors for circular economy practices in small and medium-sized enterprise supply chains: Business strategies and environmental perspectives. Bus. Strateg. Environ. 2021, 30, 2951-2965. [CrossRef]

9. Bravo-German, A.M.; Bravo-Gómez, I.D.; Mesa, J.A.; Maury-Ramírez, A. Mechanical Properties of Concrete Using Recycled Aggregates Obtained from Old Paving Stones. Sustainability 2021, 13, 3044. [CrossRef]

10. MIT Concrete Sustainability Hub. Available online: https://www.cement.org/learn/mit (accessed on 10 December 2021).

11. Muñoz Muñoz, H.A. Construcción, Interventoria y Supervisión Técnica de las Edificaciones de Concreto Estructural: Según el Reglamento Colombiano NSR-10/; Asociación Colombiana de Productores de Concreto-ASOCRETO: Bogotá, Colombia, 2015; ISBN 9789588564135.

12. Mesároš, P.; Mandičák, T. Exploitation and Benefits of BIM in Construction Project Management. IOP Conf. Ser. Mater. Sci. Eng. 2017, 245, 62056. [CrossRef]

13. Doumbouya, L.; Gao, G.; Guan, C. Adoption of the Building Information Modeling (BIM) for Construction Project Effectiveness: The Review of BIM Benefits. Am. J. Civ. Eng. Archit. 2016, 4, 74-79. [CrossRef]

14. Kim, S.; Hong, W.-K.; Kim, J.-H.; Kim, J.T. The development of modularized construction of enhanced precast composite structural systems (Smart Green frame) and its embedded energy efficiency. Energy Build. 2013, 66, 16-21. [CrossRef]

15. Hager, I.; Golonka, A.; Putanowicz, R. 3D Printing of Buildings and Building Components as the Future of Sustainable Construction? Procedia Eng. 2016, 151, 292-299. [CrossRef]

16. Hussin, J.M.; Abdul Rahman, I.; Memon, A.H. The Way Forward in Sustainable Construction: Issues and Challenges. Int. J. Adv. Appl. Sci. 2013, 2, 15-24. [CrossRef]

17. Li, L.; Li, Q.; Huang, L.; Wang, Q.; Zhu, A.; Xu, J.; Liu, Z.; Li, H.; Shi, L.; Li, R.; et al. Air quality changes during the COVID-19 lockdown over the Yangtze River Delta Region: An insight into the impact of human activity pattern changes on air pollution variation. Sci. Total Environ. 2020, 732, 139282. [CrossRef] [PubMed]

18. de De Freitas, V.P.; Delgado, J.M.P.Q. Durability of Building Materials and Components; Springer: Berlin/Heidelberg, Germany, 2013; Volume 3, ISBN 3642374751.

19. Pinto Campos, B.C. Arquitectura y Diseño Flexible Una Revisión Para una Construcción más Sostenible. Ph.D. Thesis, Universitat Politècnica de Catalunya, Barcelona, Spain, 2019; pp. 1-309.

20. Pacheco-Torgal, F.; Cabeza, L.F.; Labrincha, J.; De Magalhaes, A.G. Eco-Efficient Construction and Building Materials: Life Cycle Assessment (LCA), Eco-Labelling and Case Studies; Woodhead Publishing: Cambridge, UK, 2014; ISBN 0857097725. 
21. Caracterización Exhaustiva de los Residuos de Construcción y Demolición (RCD) que Ingresan a la Estación De Trasferencia de la Carrera 50 en la Ciudad de Cali e Identificación de su Potencial de Transformación en Eco-Productos para la Construcción. Available online: https://www.cali.gov.co/serviciospublicos/publicaciones/146621/caracterizacion-exhaustiva-de-losresiduos-de-construccion-y-demolicion-rcd-que-ingresan-a-la-estacion-de-trasferencia-de-la-carrera-50-en-la-ciudad-de-cali-e-identificacion-de-su-potencial-de-transformacion-en-eco-productos-para-la-construccion/ (accessed on 10 December 2021).

22. Maury Ramirez, A. Cementitious Materials with Air-Purifying and Self-Cleaning Properties Using Titanium Dioxide Photocatalysis; Ghent University: Ghent, Belgium, 2011.

23. Reciclaje y Cierre del ciclo de Vida de las Placas de yeso Laminado. Available online: https://www.interempresas.net/Reciclaje/ Articulos/109556-Reciclaje-y-cierre-del-ciclo-de-vida-de-las-placas-de-yeso-laminado.html (accessed on 10 December 2021).

24. Ministerio de Ambiente y Desarrollo Sostenible. Resolución No. 0404. Available online: https://www.minambiente.gov.co/wpcontent/uploads/2021/08/resolucion-0404-de-2021.pdf (accessed on 10 December 2021).

25. Pacheco-Torgal, F.; Jalali, S.; Labrincha, J.; John, V.M. Eco-Efficient Concrete, 1st ed.; Woodhead Publishing: Cambridge, UK, 2013.

26. Diosa, J.S. Experimental Analysis of the Mechanical Properties of High-Strength Concrete Made with Recycled Concrete Aggregates. Pontificia Universidad Javeriana Cali, Cali, Colombia, 2020.

27. Londoño, J. Mechanical Behavior of Precast Concrete Elements with Recycled Aggregates within the Source that Generates Them; Pontificia Universidad Javeriana Cali: Cali, Colombia, 2016.

28. Hurtado, I. Evaluation of the Effect of the Partial Replacement of Portland Cement by Ash from the Paper Industry in Mortars and Walls; Pontificia Universidad Javeriana Cali: Cali, Colombia, 2019.

29. Naranjo, A.; Colonia, A.; Mesa, J.; Maury-Ramírez, A. Evaluation of Semi-Intensive Green Roofs with Drainage Layers Made Out of Recycled and Reused Materials. Coatings 2020, 10, 525. [CrossRef]

30. Medina Medina, A.F.; Torres Rojas, D.F.; Meza Girón, G.; Villota Grisales, R.A. Design of a System to Generate Air Purification and Self-Cleaning in the Surfaces of the Colombia Avenue Tunne; Pontificia Universidad Javeriana Cali: Cali, Colombia, 2016.

31. Mesa, J.A.; Fúquene-Retamoso, C.; Maury-Ramírez, A. Life Cycle Assessment on Construction and Demolition Waste: A Systematic Literature Review. Sustainability 2021, 13, 7676. [CrossRef]

32. Life Cycle Initiative. Available online: https://www.lifecycleinitiative.org/wp-content/uploads/2021/01/Guidelines-for-SocialLife-Cycle-Assessment-of-Products-and-Organizations-2020-22.1.21sml.pdf (accessed on 10 December 2021).

33. Dong, Y.H.; Ng, S.T. A social life cycle assessment model for building construction in Hong Kong. Int. J. Life Cycle Assess. 2015, 20, 1166-1180. [CrossRef]

34. da Cruz, N.F.; Marques, R.C. Scorecards for sustainable local governments. Cities 2014, 39, 165-170. [CrossRef]

35. European Commission, Joint Research Centre. Making Sustainable Consumption and Production a Reality. A Guide for Business and Policy Makers on Life Cycle Thinking and Assessment; European Union: Brussels, Belgium, 2010. 